\title{
Influence of neutral surface position on the nonlinear stability behavior of functionally graded plates
}

\author{
T. Prakash • M. K. Singha • M. Ganapathi
}

Published online: 12 August 2008

(C) Springer-Verlag 2008

\section{Erratum to: Comput Mech}

\section{DOI 10.1007/s00466-008-0309-8}

We have found a typo error in the stiffness coefficients of Eq. (10) of the original article. The correct expressions for the stiffness coefficients $\left[A_{i j}\right]^{n s},\left[D_{i j}\right]^{n s},\left[A_{i j}\right],\left[B_{i j}\right]$ and $\left[D_{i j}\right]$ $(i, j=1,2,6)$ are

$$
\begin{aligned}
{\left[A_{i j}, D_{i j}\right]^{n s}=} & \int_{-\frac{h}{2}-C}^{\frac{h}{2}-C}\left[\bar{Q}_{i j}\right]\left(1, z_{n s}^{2}\right) d z_{n s} \\
{\left[A_{i j}, B_{i j}, D_{i j}\right] } & =\int_{-h / 2}^{h / 2}\left[\bar{Q}_{i j}\right]\left(1, z_{m s}, z_{m s}^{2}\right) d z_{m s}
\end{aligned}
$$

The online version of the original article can be found under doi:10.1007/s00466-008-0309-8.

T. Prakash · M. K. Singha $(\varangle)$

Department of Applied Mechanics,

Indian Institute of Technology Delhi, New Delhi 110 016, India

e-mail: maloy@am.iitd.ac.in

M. Ganapathi

Formerly Professor, Institute of Armament Technology, Girinagar,

Pune 411 025, India 